\title{
An Electropolymerized Pd-containing Thiophene Polymer: A Reusable Supported Catalyst for Cross-coupling Reactions
}

\author{
Vincenzo G. Albano, ${ }^{a}$ Marco Bandini, ${ }^{* a}$ Carolyn Moorlag, ${ }^{b}$ Fabio Piccinelli, ${ }^{a}$ Agostino Pietrangelo, ${ }^{b}$ \\ Simona Tommasi, ${ }^{a}$ Achille Umani-Ronchi, ${ }^{a}$ Michael O. Wolf ${ }^{* b}$ \\ ${ }^{a}$ Dipartimento di Chimica “G. Ciamician”, Università di Bologna, via Selmi 2, 40126 Bologna, Italy. \\ ${ }^{b}$ Department of Chemistry, University of British Columbia, Vancouver, BC, V6T 1Z1, Canada.
}

\section{Supporting Information}

General Methods. All reagents were purchased from Aldrich Inc. and used without further purification. All reactions were carried out under rigorous anhydrous conditions unless otherwise specified. GC-MS spectra were taken by EI ionization at $70 \mathrm{eV}$ on a Hewlett-Packard 5971 instrument equipped with GC injection. LC-electrospray ionization mass spectra were obtained using an Agilent Technologies MSD1100 single-quadrupole mass spectrometer. Analytical high performance liquid chromatography (HPLC) was performed on a liquid chromatograph equipped with a variable wavelength UV detector (deuterium lamp 190-600 nm), using a Daicel Chiralcel ${ }^{\mathrm{TM}}$ OJ column $(0.46 \mathrm{~cm}$ I.D. x $25 \mathrm{~cm})$ (Daicel Inc.). HPLC grade isopropanol (IPA) and $n$-hexane ( $n$-hex) were used as the eluting solvents. ${ }^{1} \mathrm{H}$-NMR spectra were recorded on either a Varian $200(200 \mathrm{MHz})$ or Varian $300(300 \mathrm{MHz})$ spectrometer. Chemical shifts are reported in ppm with respect to tetramethylsilane (TMS). Solution electronic absorption spectra were obtained on a Varian Cary 5000 UV-vis-near-IR spectrophotometer in methylene chloride $\left(\mathrm{CH}_{2} \mathrm{Cl}_{2}\right)$, while solid state spectra were acquired from polymeric films grown on an indium tin oxide (ITO) layer on glass. Fluorescence data was obtained on a Photon Technology International QuantaMaster fluorimeter. X-ray photoelectron spectroscopy (XPS) analysis was performed on a Leybold MAX200 equipped with an Al Ka source with a pass energy of $192 \mathrm{eV}$.

Electrochemistry. All electrochemical polymerizations were carried out using a Pine AFCBP1 bipotentiostat. The working electrode was either a platinum disk, an indium tin oxide (ITO) layer on glass, or Toray carbon paper (TGP-H030). The counter electrode was a platinum mesh and the reference electrode was a silver wire. Ferrocene was used as an internal reference in order to correct the potentials with respect to a saturated calomel electrode (SCE). The electrolyte, ${ }^{n} \mathrm{Bu}_{4} \mathrm{NPF}_{6}$, was recrystallized three times from ethanol and dried at $90{ }^{\circ} \mathrm{C}$ under vacuum for 3 days. All polymerizations were carried out in $\mathrm{CH}_{2} \mathrm{Cl}_{2}$, which had been dried by passing it through an activated alumina column.

Synthesis of 2a. In a Schlenk flask, flamed and flushed with nitrogen, 1 (110 mg, $0.17 \mathrm{mmol})$ was dissolved in $10 \mathrm{~mL}$ of a THF: $\mathrm{CH}_{2} \mathrm{Cl}_{2}$ mixture $(1: 1) .\left[\mathrm{Pd}\left(\eta^{3}-\mathrm{C}_{3} \mathrm{H}_{5}\right)(\mu-\mathrm{Cl})\right]_{2}(32.3 \mathrm{mg}, 0.085 \mathrm{mmol})$ was added and the mixture was stirred at room temperature for $4 \mathrm{~h} . \mathrm{AgBF}_{4}(35.6 \mathrm{mg}, 0.17 \mathrm{mmol})$ was added and the mixture was left to stir overnight in the dark. The mixture was then filtered and the solvent removed under reduced pressure. The product was dried under vacuum. The residue was washed with $\mathrm{Et}_{2} \mathrm{O}(8 \mathrm{~mL})$ and the Pd complex was recovered as an air stable dark yellow solid by filtration (125 mg, 85\% yield). UV/vis $\left(\mathrm{CH}_{2} \mathrm{Cl}_{2}\right) \lambda \max / \mathrm{nm}\left(\varepsilon / \mathrm{cm}^{-1} \mathrm{~mol}^{-1} \mathrm{~L}\right): 360(44000), 248(20000) . \mathrm{IR}\left(\mathrm{KBr}, \mathrm{cm}^{-1}\right)$ 
3250, 3110, 2932, 2860, 1615, 1450, 1083, 800. ESI-MS: $783\left(\left[\mathrm{Pd}\left(\eta^{3}-\mathrm{C}_{3} \mathrm{H}_{5}\right)(\mathbf{1})\right]^{+}\right)$. Anal. $\mathrm{C}_{35} \mathrm{H}_{35} \mathrm{~N}_{2} \mathrm{PdS}_{6} \mathrm{BF}_{4}$ requires C, 48.36; H, 4.06; N, 3.22. Found: C, 48.31; H, 4.40; N, 3.57\%.

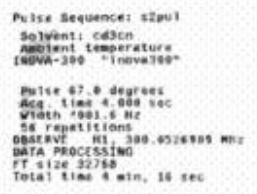

Allyl-Pd species

$A, B$ and $C$

Scheme 1 (SI). ${ }^{1} \mathrm{H}-\mathrm{NMR}\left(300 \mathrm{MHz}, \mathrm{CD}_{3} \mathrm{CN}\right.$, rt) of $2 \mathrm{a}$. The three sets of allyl protons are indicated. Diagnostic signals. A) $5.82-5.91(\mathrm{~m}, 1 \mathrm{H}), 3.93(\mathrm{p} \mathrm{t}, J=6.2 \mathrm{~Hz}, 2 \mathrm{H}), 3.38(\mathrm{~d}, J=12.0 \mathrm{~Hz}, 1 \mathrm{H}), 3.05(\mathrm{~d}, J=12.0 \mathrm{~Hz}, 1 \mathrm{H})$; B) 5.53$5.65(\mathrm{~m}, 1 \mathrm{H}), 4.16(\mathrm{br} \mathrm{d}, J=6.6 \mathrm{~Hz}, 2 \mathrm{H}), 3.07$ (d, $J=12.2 \mathrm{~Hz}, 2 \mathrm{H})$; C) 5.19-5.36 (m,1 H), $2.94(\mathrm{~d}, J=12.1 \mathrm{~Hz}, 1 \mathrm{H})$, $2.69(\mathrm{~d}, J=6.5 \mathrm{~Hz}, 2 \mathrm{H}), 2.52(\mathrm{~d}, J=12.9 \mathrm{~Hz}, 1 \mathrm{H})$. The assignment of the allyl proton sets A, B and C was made by ${ }^{1} \mathrm{H}-\mathrm{NMR}$ decoupling experiments.

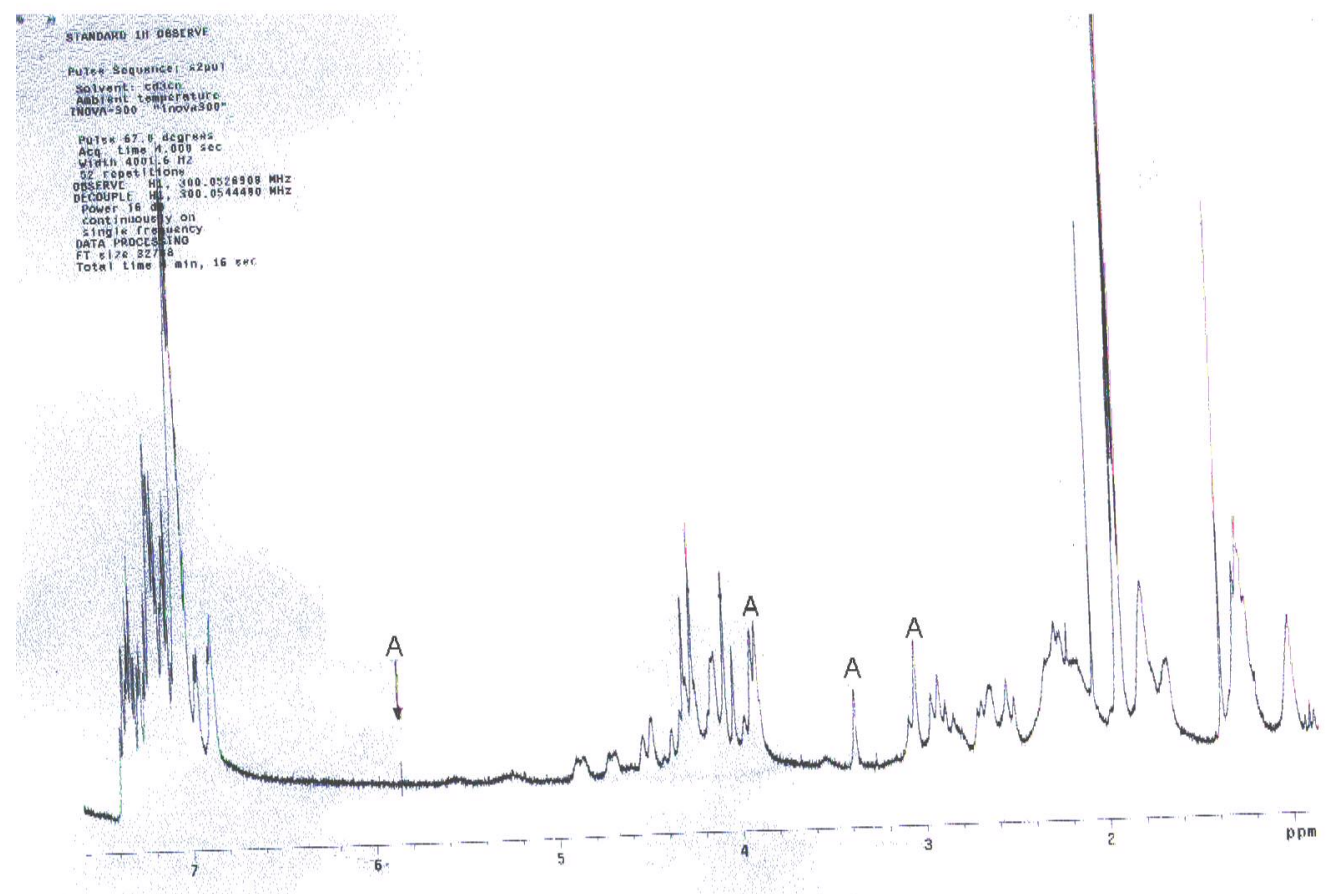




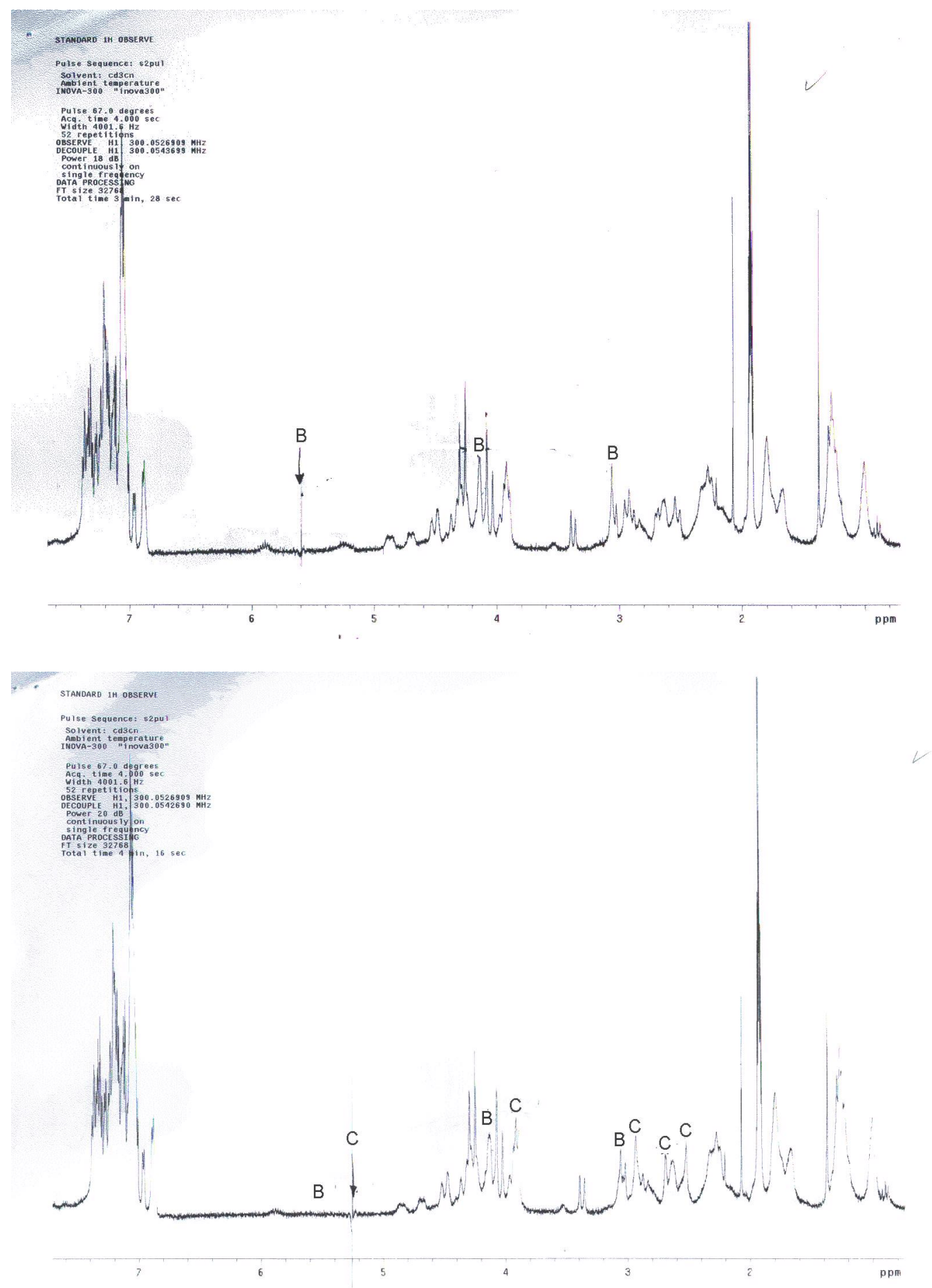

Scheme 2 (SI). ${ }^{1} \mathrm{H}$-NMR (300 MHz, $\mathrm{CD}_{3} \mathrm{CN}$, rt) saturation-transfer experiments for assignment of allyl protons of $2 \mathrm{a}$. 

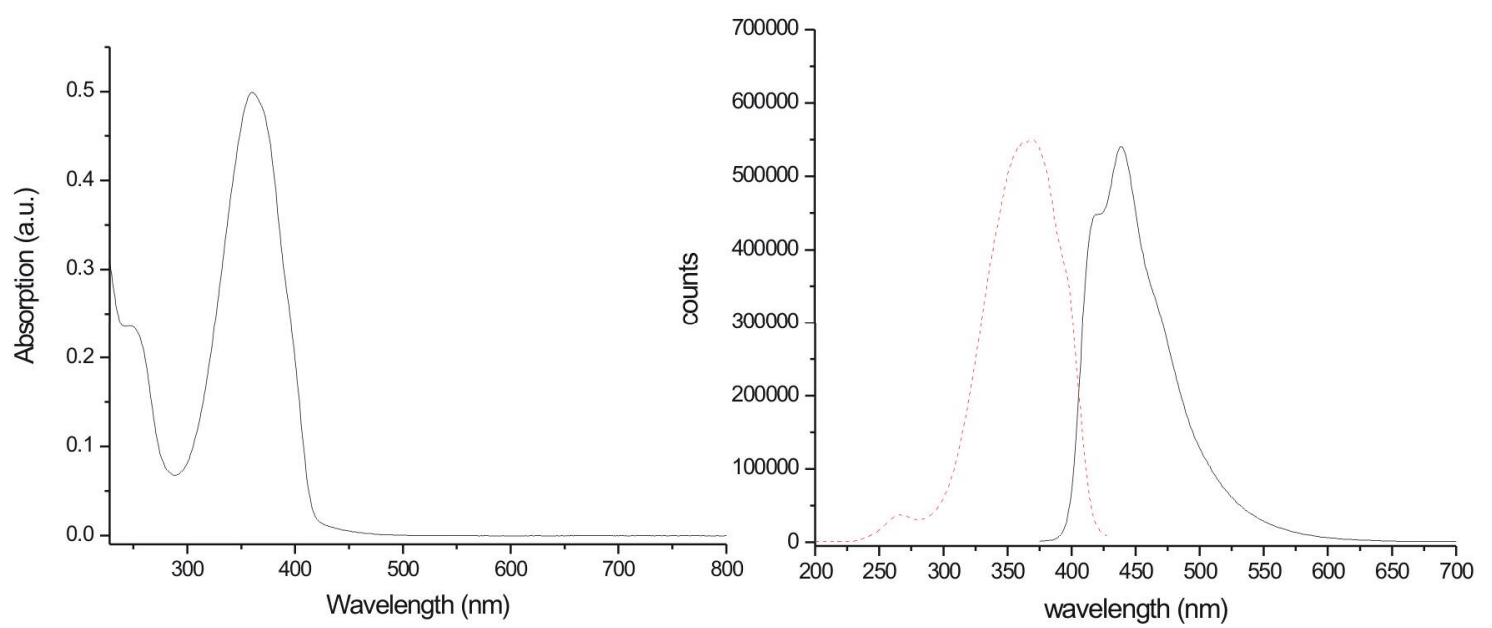

Scheme 3 (SI). UV-vis absorption spectrum of $2 \mathbf{a}$ in $\mathrm{CH}_{2} \mathrm{Cl}_{2}$ (left), excitation and emission spectrum of $\mathbf{2 a}$ in $\mathrm{CH}_{2} \mathrm{Cl}_{2}$ (right).

Synthesis of 2b. In a Schlenk flask, flamed and flushed with nitrogen, $1(27 \mathrm{mg}, 0.043 \mathrm{mmol})$ was dissolved in $10 \mathrm{~mL}$ of a THF: $\mathrm{CH}_{2} \mathrm{Cl}_{2}$ mixture $(1: 1,3.6 \mathrm{~mL}) .\left[\mathrm{Pd}\left(\eta^{3}-\mathrm{C}_{3} \mathrm{H}_{5}\right)(\mu-\mathrm{Cl})\right]_{2}(7.8 \mathrm{mg}, 0.022 \mathrm{mmol})$ was added and the mixture was stirred at room temperature for $4 \mathrm{~h} . \mathrm{NH}_{4} \mathrm{PF}_{6}(7.0 \mathrm{mg}, 0.043 \mathrm{mmol})$ was added and the mixture was left stirring overnight in the dark. The mixture was then filtered and the solvent removed under reduced pressure. The product was dried under vacuum. The residue was washed with $\mathrm{Et}_{2} \mathrm{O}(5 \mathrm{~mL})$ and the desired $\mathrm{Pd}$-complex was recovered as an air stable yellow solid by filtration (37 mg, 95\% yield. IR $\left(\mathrm{KBr}, \mathrm{cm}^{-1}\right)$ 3248, 3105, 2940, 2855, 1615, 1449, 1083, 810. ESI-MS (positive scan): $783\left(\left[\operatorname{Pd}\left(\eta^{3}-\mathrm{C}_{3} \mathrm{H}_{5}\right)(\mathbf{1})\right]^{+}\right)$; ESI-MS (negative scan): $146\left(\mathrm{PF}_{6}{ }^{-}\right)$.

Electrochemical Polymerization. The electrochemical study of 2a was performed in a single compartment cell under $\mathrm{N}_{2}$ atmosphere using a platinum disc as the working electrode, a platinum mesh as a counter electrode, and a silver wire as a reference electrode. All electrolyte solutions consisted of ${ }^{n} \mathrm{Bu}_{4} \mathrm{NPF}_{6}(0.1 \mathrm{M})$ dissolved in dry $\mathrm{CH}_{2} \mathrm{Cl}_{2}$. A saturated solution of monomer $2 \mathbf{a}(0.1 \mathrm{mM})$ was oxidatively polymerized by sweeping the potential of the electrode between +0.7 and $+1.4 \mathrm{~V}$ (versus $\mathrm{Fc} / \mathrm{Fc}^{+}$) at a scan rate of $100 \mathrm{mV} / \mathrm{s}$ for a total of 10 cycles (see Fig. 2). Polymer films used for catalysis and UV/vis studies were grown on Toray carbon paper (TGP-H-030) and indium tin oxide working electrodes respectively, by sweeping the potential between 0.0 and $+1.0 \mathrm{~V}$ at a scan rate of $100 \mathrm{mV} / \mathrm{s}$ for a total of $10 \mathrm{cycles}$, and finally rinsed with $\mathrm{CH}_{2} \mathrm{Cl}_{2}$. 


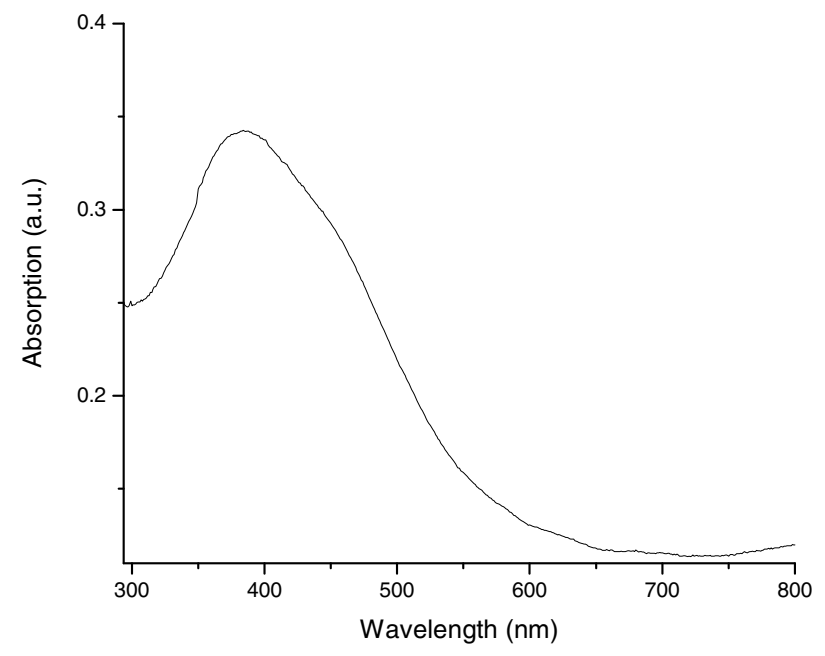

Scheme 4 (SI). UV/vis absorption spectrum of poly-2a grown on ITO.

Typical reaction procedure for Suzuki reaction. A two-neck $10 \mathrm{~mL}$ round-bottom flask equipped with a condenser was charged with a $6 \mathrm{~mL}$ mixture of toluene: $\mathrm{MeOH}(2: 1), 40 \mu \mathrm{L}$ of 2-fluoro-iodobenzene $(0.34 \mathrm{mmol}), 83 \mathrm{mg}$ of $\mathrm{PhB}(\mathrm{OH})_{2}(0.68 \mathrm{mmol})$, and $\mathrm{K}_{2} \mathrm{CO}_{3}(145 \mathrm{mg}, 0.68 \mathrm{mmol})$. The modified electrode (content of [Pd] about $0.5 \%$ respect to the iodoarene) was then introduced in the flask and the solution was refluxed overnight without stirring. After $40 \mathrm{~h}$ an aliquot of the solution was drawn and analyzed by GC (conv. 91\%). GC-MS (m/z): 51(8), 63(7), 75(10), 85(13), 133(14), 171(40), 172(100).

\section{Typical reaction procedure for Heck reaction.}

A two-neck $10 \mathrm{~mL}$ round-bottom flask equipped with a condenser was charged with a $4 \mathrm{~mL}$ mixture of toluene: $\mathrm{CH}_{3} \mathrm{CN}$ (1:1), $18 \mu \mathrm{L}$ of iodobenzene $(0.14 \mathrm{mmol}), 50 \mu \mathrm{L}$ of ethyl acrylate $(0.55 \mathrm{mmol})$, and freshly distilled TEA (38 $\mu \mathrm{L}, 0.28$ $\mathrm{mmol})$. The modified electrode (content of [Pd] about $1 \%$ respect to the iodobenzene) was then introduced in the flask and the solution was refluxed overnight without stirring. An aliquot of the solution was drawn and analyzed by GC (conv. 87\%). GC-MS (m/z): 77(35), 103(60), 131(100), 162(60).

Typical reaction procedure for Sonogashira reaction. A two-neck $10 \mathrm{~mL}$ round-bottom flask equipped with a condenser was charged with $151 \mu \mathrm{L}$ of a freshly distilled TEA, $37 \mu \mathrm{L}$ of PhCCH $(0.34 \mathrm{mmol}), 80 \mu \mathrm{L}$ of 2-fluoroiodobenzene $(0.68 \mathrm{mmol})$. The modified electrode (content of $[\mathrm{Pd}]$ about $0.5 \%$ respect to the iodoarene) was then placed in the flask and the solution was heated to $80^{\circ} \mathrm{C}$ for the specified time without stirring. The reaction conversion was determined by GC-MS by drawing an aliquot of the reaction mixture. GC-MS ( $\mathrm{m} / \mathrm{z})$ : 51(3), 75(8), 85(10), 98(15), 144(9), 170(18), 175(15), 196(100).

\section{Typical reaction procedure for intramolecular Heck reaction.}

A two-neck $10 \mathrm{~mL}$ round-bottom flask equipped with a condenser was charged with $1.0 \mathrm{~mL}$ of anhydrous DMA, $17 \mathrm{mg}$ of 2-iodoanilide $(0.05 \mathrm{mmol}$,) and DIPEA $(17 \mu \mathrm{L}, 0.1 \mathrm{mmol})$. The modified electrode (content of [Pd] about 3\% respect to the iodo-compound) was then introduced in the flask and the solution was heated at $80^{\circ} \mathrm{C}$ for $48 \mathrm{~h}$. Progress of the reaction was monitored by TLC and HPLC. Once the reaction was complete, the mixture was diluted with $\mathrm{Et}_{2} \mathrm{O}$ and 
washed with a saturated solution of $\mathrm{NaHCO}_{3}$. The organic layer was finally washed with brine, dried over $\mathrm{Na}_{2} \mathrm{SO}_{4}$ and concentrated by removing solvent under reduced pressure. The crude product was purified by flash chromatography $(c$ hex:AcOEt 8:2). Viscous oil, (57\% yield); ESI-MS: $188(\mathrm{M}+1) ;{ }^{1} \mathrm{H}-\mathrm{NMR}\left(200 \mathrm{MHz}, \mathrm{CDCl}_{3}\right): \delta 1.51(\mathrm{~s}, 3 \mathrm{H}), 3.23(\mathrm{~s}$, $3 \mathrm{H}), 5.12(\mathrm{~d}, J=7.8 \mathrm{~Hz}, 1 \mathrm{H}), 5.19(\mathrm{~s}, 1 \mathrm{H}), 5.97$ (dd, $J=10.8,17.2 \mathrm{~Hz}, 1 \mathrm{H}), 6.87$ (d, $J=7.4 \mathrm{~Hz}, 1 \mathrm{H}), 7.06-7.35$ (m, $3 \mathrm{H})$. The ee of the product $(0 \%)$ was determined by chiral HPLC (Chiralcel OJ: IPA: $n$-hex 5:95, $0.5 \mathrm{~mL} / \mathrm{min}$ flow, 220 $\mathrm{nm}, \mathrm{R}_{\mathrm{t}}: 17.1 \mathrm{~min}$; $\mathrm{R}_{\mathrm{t}}: 18.5 \mathrm{~min}$.).

\section{Recovery and reuse of the modified electrode in Suzuki reaction}

Optimal reaction conditions were employed for each run. The electrode was then removed from the reactor, washed with boiling $\mathrm{MeOH}$, dried under vacuum and reused without further purifications.

Table 1 (SI)

\begin{tabular}{|c|c|c|}
\hline \multicolumn{3}{|c|}{ Suzuki } \\
\hline Run & Time (h) & Conv(\%) \\
\hline 1 & 40 & 91 \\
\hline 2 & 40 & 98 \\
\hline 3 & 40 & 98 \\
\hline 4 & 48 & 92 \\
\hline 5 & 72 & 89 \\
\hline
\end{tabular}

Crystallography for $\mathbf{2 b}$. Crystal data and details of the data collection are reported in Table 2 (S1). The diffraction experiments were carried out at room temperature on a Bruker SMART Apex II CCD based diffractometer using graphite monochromated Mo-K $\alpha$ radiation $(\lambda=0.71073 \AA$ ). Intensity data were measured over full diffraction sphere using $0.3^{\circ}$ wide $\omega$ scans. The software $\mathrm{SMART}^{1}$ was used for collecting frames of data, indexing reflections and determination of lattice parameters. The collected frames were then processed for integration by software SAINT ${ }^{1}$ and an empirical absorption correction was applied with $\mathrm{SADABS}^{2}$. The structure was solved by direct methods (SIR97) $^{3}$ and subsequent Fourier syntheses, and refined by full-matrix least-squares calculations on $F^{2}$ (SHELXTL) $^{4}$ attributing anisotropic thermal parameters to all non-hydrogen atoms except those belonging to the outher thienyl rings. The thiophene ring containing $\mathrm{S}(5)$ shows some positional disorder between the $\mathrm{S}$ and $\mathrm{C}$ (ortho) atoms generated by $180^{\circ}$ rotation around the $\mathrm{C}$ (inner thienyl)-C(outer thienyl) bond. The site occupancies of the disordered atoms were constrained to equal unity over the two positions. The independent site occupation factor was refined to values 0.67 for $\mathrm{S}(5)$ and 0.33 for $\mathrm{S}(5 \mathrm{a})$. The methylene, methyne, allyl and aromatic hydrogen atoms, which were located in the $\Delta \mathrm{F}$ map, were placed in calculated positions and refined with idealized geometry with $U_{\text {iso }}(H)=$ $1.2 \mathrm{U}_{\mathrm{eq}}(\mathrm{C})$, whereas the aminic protons were isotropically refined. 
(a)

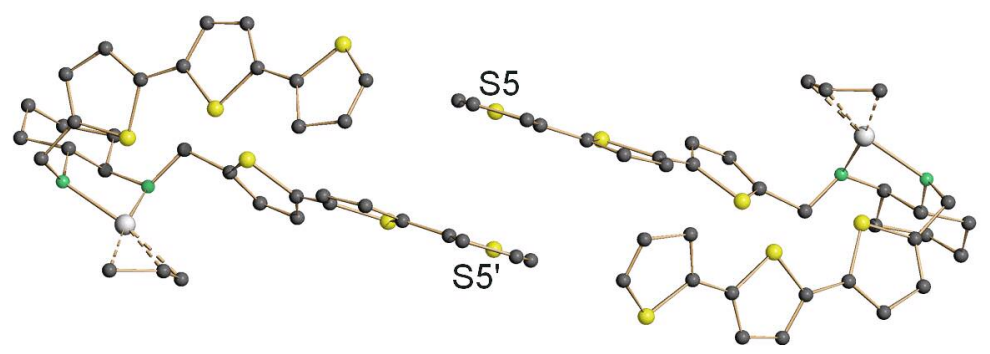

(b)

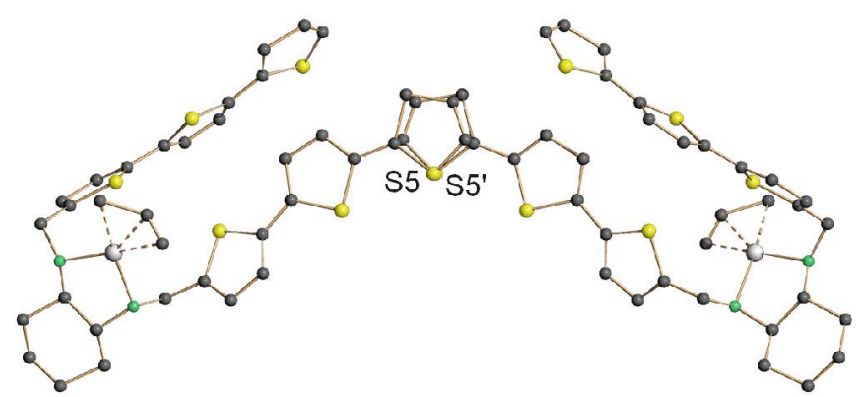

Figure 1 (S1) (a) View perpendicular to $b$ showing the $\pi-\pi$ face to face stacking interaction. (b) View perpendicular to the thiophene ring containing $S(5)$ (distance between the two centroids 3.79(1) A) Hydrogen atoms omitted for clarity.

Table 2 (SI). Crystal data and experimental details for $\mathbf{2 b .}$

\section{Compound}

Formula

Fw

$\mathrm{T}, \mathrm{K}$

$\lambda, \AA$

Crystal symmetry

Space group

$a, \AA$

$b, \AA$

c, $\AA$

$\alpha,{ }^{\circ}$

$\beta$,

$\gamma,{ }^{\circ}$
$2 b$

$\mathrm{C}_{35} \mathrm{H}_{35} \mathrm{~F}_{6} \mathrm{~N}_{2} \mathrm{P}$ Pd S

927.38

293

0.71073

Monoclinic

$C 2$

20.049(7)

10.594(4)

19.372(7)

90

103.020(6)

90 
Cell volume, $\AA^{3}$

Z

$\mathrm{D}_{\mathrm{c}}, \mathrm{Mg} \mathrm{m}^{-3}$

$\mu\left(\right.$ Mo-K $\left._{\alpha}\right), \mathrm{mm}^{-1}$

$\mathrm{F}(000)$

Crystal size/ $\mathrm{mm}$

$\theta$ limits, ${ }^{\circ}$

Reflections collected

Unique obs. reflections $\left[\mathrm{F}_{\mathrm{O}}>4 \sigma\left(\mathrm{F}_{\mathrm{O}}\right)\right]$

Goodness-of-fit-on $\mathrm{F}^{2}$

$\mathrm{R}_{1}(\mathrm{~F})^{\mathrm{a}}, \mathrm{wR}_{2}\left(\mathrm{~F}^{2}\right)^{\mathrm{b}}$

Absolute structure parameter

Largest diff. peak and hole, e. $\AA^{-3}$
4009(3)

4

1880

$0.45 \times 0.15 \times 0.10$

$1.08-23.36$

12368

$5786\left[\mathrm{R}_{\mathrm{int}}=0.0314\right]$

1.002

$0.0589,0.1620$

$0.00(5)$

0.735 and -0.738

$\mathrm{a}_{1}=\Sigma|| \mathrm{Fo}|-| \mathrm{Fc}|/ \Sigma| \mathrm{Fo} \mid .{ }^{\mathrm{b}}{ }_{\mathrm{wR}}=\left[\Sigma \mathrm{w}\left(\mathrm{Fo}^{2}-\mathrm{Fc}^{2}\right)^{2} / \Sigma \mathrm{w}\left(\mathrm{Fo}^{2}\right)^{2}\right]^{1 / 2}$ where $\mathrm{w}=1 /\left[\sigma^{2}\left(\mathrm{Fo}^{2}\right)+(a \mathrm{P})^{2}+b \mathrm{P}\right]$ where $\mathrm{P}=$ $\left(\mathrm{Fo}^{2}+2 \mathrm{Fc}^{2}\right) / 3$.

1 SMART \& SAINT Software Reference Manuals, version 5.051 (Windows NT Version), Bruker Analytical X-ray Instruments Inc.: Madison, Wi, 1998.

2 Sheldrick, G.M. SADABS, program for empirical absorption correction, University of Göttingen, Germany, 1996.

3 Altomare, A.; Burla, M.C.; Cavalli, M.; Cascarano, G.L.; Giacovazzo, C.; Guagliardi, A.; Moliterni, A.G.G.; Polidori, G.; Spagna, R. J. Appl. Cryst. 1999, 32, 115.

4 Sheldrick, G.M. SHELXTLplus Version 5.1 (Windows NT version) Structure Determination Package; Bruker Analytical X-ray Instruments Inc.: Madison, Wi, 1998. 